\title{
Resource assessment of Bel (Aegle marmelos) and potentiality to establish its processing enterprise in Tanahun district of Nepal
}

\begin{abstract}
K. Baral ${ }^{1}$ and B. R. Upreti ${ }^{2}$
Participatory resource assessment of Aegle marmelos was carried out in six community forests (CFs) of the Jamune VDC of Tanahun district to find out potentiality for establishing community-based $A$. marmelos processing enterprise in the locality. Circular sample plots of 500 square meters were laid down taking $5 \%$ sampling intensity. The DBH (Diameter at Breast Height) and height of trees on the sample plots were measured and classified them into three DBH classes $(10-20 \mathrm{~cm}, 20-30$ $\mathrm{cm}$ and more than $30 \mathrm{~cm}$ ). The number of the fruits on the three branches of each A. marmelos tree - one lower branch, one middle branch and one top branch were counted, the average number of fruits on the three branches calculated and multiplied with the number of the branches of the tree to find out the average number of fruits per tree. By calculating the weighted mean of the three different $\mathrm{DBH}$-class trees, the total number of the fruits was estimated. The study found $54,830 \mathrm{~kg}$ of harvestable amount of $A$. marmelos fruit in the studied six CFs which can produce $19190.5 \mathrm{~kg}$ of pulp per year. Thus, establishment of juice processing enterprise was found to be feasible in the locality. Nevertheless, some shortcomings related to the management of $A$. marmelos resource, such as lacking of information and management options for A. marmelos trees in the Operation Plans (OPs), lower regeneration status of A. marmelos trees, higher incidences of forest-fire and open grazing in the CFs, were also recorded. The study suggests for carrying out awareness-generating activities targeted to the CF user group members, revision of OPs and incorporation of $A$. marmelos resource information and management options and preparation and implementation of regeneration protection plan against forest fire and grazing.
\end{abstract}

Key words: Aegle marmelos, enterprise, regeneration protection

A egle marmelos (L.) Correa is a mediumsized deciduous tree. Its local names are Bel (Nepali), Vilva, Biranab (Sanskrit) Bengal queen (English) etc. It belongs to the Rutacae family and Aurantioideae sub-family. Its branches are thorny and the bark is gray in color. The leaves are trifoliate with numerous oil glands. Flowers of A. marmelos are greenish white and bisexual in nature. Flowering starts during April-June, fruiting occurs from April to July of next season (Parajuli et al., 1998; Kunwar, 2006; Pathak et al., 2015). A. marmelos trees are generally found in the outer Himalayas, Siwaliks and Tarai with altitudes up to $1500 \mathrm{~m}$. In Nepal, A. marmelos is distributed abundantly in the Siwalik region, Inner Tarai, and lower valley region mostly at riverside having sandy soil at $150-1,220 \mathrm{~m}$ altitude (Shrestha and Shrestha, 2005). It prefers comparatively drier and sunny or warmer aspect with well-drained loamy soil. It is found growing naturally in the mixed stands of Shorea robusta, Terminalia tomentosa, Adina cordifolia and so on in the Tarai, Bhabar and the Mid-hills. It copes with a wide range of soil conditions $(\mathrm{pH}$ range $5-10$ ), is tolerant to water-logging and has an unusually wide temperature tolerance (from $7^{\circ} \mathrm{C}$ to $48^{\circ} \mathrm{C}$ ). It requires a pronounced dry season to give fruit (Bhattrai, 2001; Poudel, 2005).

A. marmelos has both medicinal and religious values. The ripe fruit is taken scientifically as brain tonic and energetic, and it improves eternal power and longevity. Moreover, it is considered as a very good medicine for the patients suffering

${ }^{1}$ District Forest Office, Baitadi, Nepal. E-mail: baralkedar@hotmail.com

${ }^{2}$ District Forest Office, Tanahun, Nepal 
from constipation. Unripe A. marmelos fruit is prescribed for curing cholera, diarrhea, worms and other stomach diseases because of its antibacterial, antiviral and anthelmintic properties. The leaves are excellent medicine for the diabetic patients (Shrestha, 2003). Furthermore, A. marmelos fruit contains highvalued chemical compounds including alkaloids, coumarone, steroids, mucilage pectin, sugar, and tannin whilst the leaves produce an essential oil. The fruit has high nutritional value containing tonics, vitamins, carbohydrates, proteins, fats and a range of medicinal substances (Bhattrai, 2001).

Juice, jam, candy, sweets and other food products can be made from the fruit in addition to a range of Ayurvedic medicines. No substance poisonous to humans has been found in A. marmelos fruit (Poudel, 2005). Juice of the ripen A. marmelos fruit has very good market in Nepal and India. A. marmelos is identified as a major high- valued non-timber forest product (NTFP) which has great potentiality to improve the livelihood of the Community Forest User Groups (CFUGs) members in Nepal. Considering this fact, a few A. marmelos juice factories have been established in different parts of the nation in the initiation of District Forest Offices (DFOs), the Federation of Community Forestry Users Nepal (FECOFUN), Community Forests (CFs) and other organizations. The Tamakoshi Bel Juice Processing Company of Eastern Nepal and the Nabadurga Community Bel Juice Factory of Bardiya district in Midwestern Nepal are some successful examples of A. marmelos enterprises run by the CFUGs (Baral and Khadka, 2007).

The CFs of the Jamune Village Development Committee (VDC) of Tanahun district is reported to have substantial number of $A$. marmelos trees, and the local people are energetic to establish $A$. marmelos processing enterprises to support the livelihood of the members. In this regard, the current study was carried out in 2014 with the objectives of carrying out resource inventory of the A. marmelos trees, finding out the total number and annual fruiting trees, assessing the total and annual harvestable weight of fruits and finding out the potential to establish A. marmelos processing factory at Jamune VDC of Tanahun district by estimating pulp production potential of the six CFs.

\section{Materials and methods}

\section{Study site}

Tanahun is a hilly district with altitude ranging from $187-2,325 \mathrm{~m}$ above the mean sea level. This district is located between $27^{\circ} 36^{\prime}-28^{\circ} 05^{\prime}$ North latitude and between $83^{\circ} 57^{\prime}$ and $84^{\circ} 34^{\prime} \mathrm{E}$ longitude. The area of the district is 1,560 square kilometers out of which the forest area occupies $50.5 \%$ (788 sq. km). Altogether, 545 CFs have been handed over to 52,989 households covering 37689.71 hectares (ha) of forest land in the district (DFO, 2014).

Jamune VDC lies almost at the centre of the district. Till now, $12 \mathrm{CFs}$ have been handed over to the 1951 households covering 1,105.21 ha of forest land in this VDC (DFO, 2014). Among them, the six CFs selected for the study purpose (Table 1) were reported to have higher number of A. marmelos trees, and thus have ample potentialities to run the A. marmelos processing enterprise. These CFs lie in a cluster which is approximately $15 \mathrm{~km}$ far from Damauli, the district headquarters (Fig. 1).

Table 1: Brief descriptions of the six studied CFs

\begin{tabular}{llrrrr}
\hline S.N. & Name and address of CFs & $\begin{array}{c}\text { Total area } \\
\text { (ha) }\end{array}$ & $\begin{array}{c}\text { Number of } \\
\text { households }\end{array}$ & Population & Reference \\
\hline 1. & Poseli CF, Jamune-1 & 48.75 & 93 & 489 & CFOP 2008a \\
2. & Barchyang CF, Jamune-2 & 160.00 & 93 & 596 & CFOP 2008b \\
3. & Jantang Pandhera CF, Jamune-3 & 104.90 & 134 & 815 & CFOP 2008c \\
4. & Bhirpani CF, Jamune-4 & 124.00 & 156 & 930 & CFOP 2008d \\
5. & Uma Chwok CF, Jamune-5 & 94.50 & 181 & 996 & CFOP 2008e \\
6. & Siddha Batasan CF, Jamune-6 & 115.7 & 90 & 495 & CFOP 2008f \\
\hline & Total & $\mathbf{6 4 7 . 8 5}$ & $\mathbf{7 4 7}$ & $\mathbf{4 , 3 2 1}$ & \\
\hline
\end{tabular}




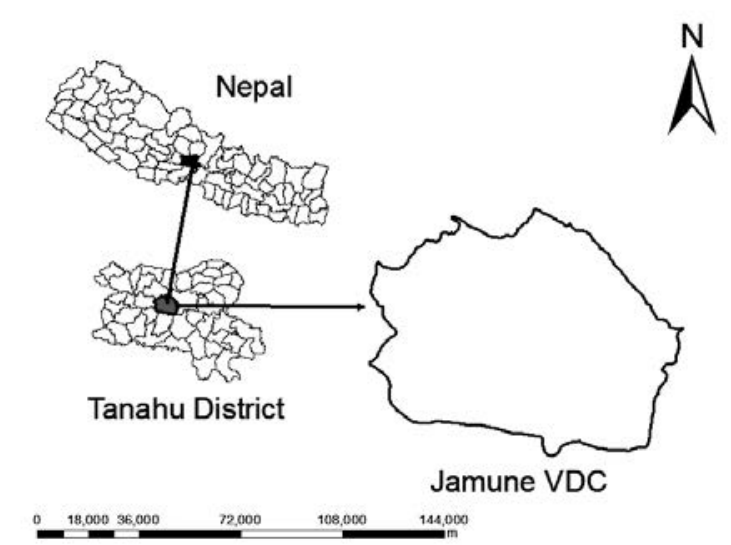

Fig. 1: Map showing the location of the study area

The forests in all the studied CFs are, moreover, sub-tropical mixed-hardwoods with $S$. robusta, T. tomentosa, A. cordifolia, Acacia catechu, Bombax ceiba, Schima wallichii and Castanopsis indica as the major tree species. Apart from A. marmelos, other important NTFPs found in the CFs are Asparagus racemosus, T. bellirica and T. chebula. The major wildlife species found in the CFs are leopard, jackal, fox, monkey, rabbit, squirrel, civet and jungle cat.

\section{Sampling design}

A participatory resource inventory was carried out involving the members of the CFUGs and the Tanahun DFO field staff. The blocks of the studied CFs were stratified into the A. marmelosdominant blocks and non- $A$. marmelos-dominant blocks; all the blocks having more than $50 \%$ A. marmelos trees out of the total trees were categorized as $A$. marmelos-dominant while the blocks having less than $50 \%$ A. marmelos trees were categorized as non- A. marmelos -dominant blocks. In course of the stratification of the forests into such blocks, full observation of the blocks and consultation with the concerned CFUG members were done rigorously. In the A. marmelos-dominant blocks, inventory was carried out following the rules mentioned in the NTFPs Inventory Guidelines, 2013 (DoF, 2013). In the case of the non-dominant blocks, all the $A$. marmelos trees counted and their measurements were taken.

\section{Plot measurement}

\section{A. marmelos-dominant blocks}

First of all, 5\% sample out of the whole area of the blocks was taken, and a total of 117 circular sample plots of 500 square meters were laid. Transect lines were drawn on the map of blocks and first sample plot was laid down on the starting point of transect line. Remaining sample plots were taken on the transect line and plot to plot distance was fixed by following the NTFP Inventory Guidelines published by Department of Forest (2013). Then, the diameters (at breast height) and heights of all the A. marmelos trees were measured and recorded; the A. marmelos trees were classified into three diameter $(\mathrm{DBH})$ classes viz. $10-20 \mathrm{~cm}, 20-30 \mathrm{~cm}$ and more than $30 \mathrm{~cm}$. After that, the number of the fruits, on the three branches (of each A. marmelos tree)- one lower branch, one middle branch and one top branch, were harvested, counted and weighed separately as per the above mentioned DBH classes. Then the pulp content of all the harvested fruits were weighed and the average number of fruits and their pulp content per tree within each of the aforementioned three DBH classes were calculated. Finally, the total number of the fruits and pulp content of the blocks were found out.

\section{Non-A.marmelos-dominant blocks}

In the case of the non- $A$. marmelos-dominant blocks, all the A. marmelos trees were first counted and classified into the aforementioned three DBH classes. The classified numbers of the trees were then multiplied with their corresponding average figures per DBH class calculated earlier in the case of the A. marmelos-dominant blocks so as to find out the total amount of fruits and their pulp.

\section{Results and discussion}

\section{Assessment of the fruiting A. marmelos trees}

Altogether, 7,832 A. marmelos trees were found in the six CFs. Out of this number, only 5,483 trees $(70 \%)$ were found to be fruiting, and the rest 2,349 (30\%) were non-fruiting (Fig. 2). This result is similar to those of Baral and Khadka (2007) who found $24 \%$ non-fruiting A. marmelos trees in the CFs of Bardiya district. Most of the trees located under the Sal canopy and steep sloppy area were found to be non-fruiting. 


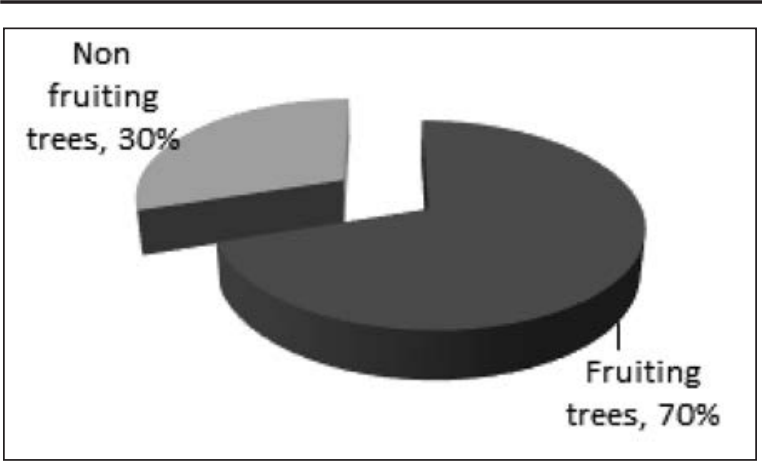

Fig. 2: Presence of fruiting and non-fruiting trees in the studied CFs

Out of the total area of 647.85 ha of all the six $\mathrm{CFs}$, only 117.0 ha $(18 \%)$ had the A. marmelos trees both in the A. marmelos-dominant and non-A. marmelos-dominant blocks (Table 2). In the case of the dominant blocks, the entire blocks were incorporated as effective areas; however in the case of the non-A. marmelos-dominant blocks, consultation with the concerned CFUG members and field observation were done so as to estimate their areas. In this regard, the Siddha Batasan CF had highest number of $A$. marmelos trees $(1,738)$ whereas the Poseli CF had the least (778 trees). On an average, 8 fruiting $A$. marmelos trees were found per ha in the CFs. The maximum number of fruits found in a A. marmelos tree was recorded as 450 and the minimum as 50 . The number of seedlings and saplings together was found to be almost half the number of mature trees, and only 33 seedlings and saplings together per hectare were observed (Table 2). This indicated the very poor regeneration status of $A$. marmelos trees in the studied CFs on the one hand and higher threat to the conservation as well as sustainability of the species on other hand in this locality.

\section{Availability of A. marmelos fruits and pulp}

The weighted mean of $A$. marmelos fruits in different DBH class was found 150 . Hence, a total number of $822,450 \mathrm{~A}$. marmelos fruits are estimated in the six studied CFs which are equal to the $137,075 \mathrm{~kg}$ at the average rate of 6 fruits per $\mathrm{kg}$ weight. Likewise, average production of fruits was calculated $212 \mathrm{~kg}$ per hectares (Table 3).

\section{Harvesting amount of A. marmelos fruits and production of pulp}

The total estimated numbers of A. marmelos fruits available in the six CFs was 822,450. Nevertheless, due to the difficult terrain and inaccessibility, large quantity of fruits could not be harvested. In the fruiting season, monkeys and bears used to damage the fruits. On the other hand, some fruits should be left in the trees for full ripening and dispersal so as to promote natural regeneration. The CFUG members were found to have long experience on A. marmelos fruit harvesting. Based on the rigorous discussion with the CFUG members who have been actively participating in its harvesting, we concluded that only $40 \%$ of the total fruits could be harvested. Hence, the total amount of harvestable $A$. marmelos fruits was estimated to be 328,980 $(54,830 \mathrm{~kg})$. Different literatures (Kunwar, 2006; Baral and Khadka, 2007) show that the pure pulp is only $35 \%$ (on an average) of the total weight of the A. marmelos fruits while the remaining $65 \%$ belong to the bark, fibers, seeds and the wastage. Thus, pulp production potential of the six CFs was found to be $19,190.5 \mathrm{~kg}$ per year (Table 3).

Table 2 : Description of A. marmelos trees in the studied CFs

\begin{tabular}{llrrrrrr}
\hline S.N. & $\quad$ Name and address of CFs & $\begin{array}{c}\text { Total area } \\
\text { (ha) }\end{array}$ & $\begin{array}{c}\text { Effective } \\
\text { area (ha) }\end{array}$ & $\begin{array}{c}\text { No. of A. } \\
\text { marmelos } \\
\text { trees }\end{array}$ & $\begin{array}{c}\text { No. of } \\
\text { fruiting } \\
\text { trees }\end{array}$ & $\begin{array}{c}\text { No. of } \\
\text { fruiting } \\
\text { trees /ha }\end{array}$ & $\begin{array}{c}\text { No. of } \\
\text { seedlings }+ \\
\text { saplings }\end{array}$ \\
\hline 1. & Poseli CF, Jamune-1 & 48.75 & 9.0 & 778 & 545 & 11 & 910 \\
2. & Barchyang CF Jamune-2 & 160.00 & 32.0 & 1,340 & 938 & 6 & 520 \\
3. & Jyantang Pandhera CF Jamune-3 & 104.90 & 18.0 & 1,330 & 931 & 9 & 610 \\
4. & Bhirpani CF Jamune-4 & 124.00 & 20.0 & 1,423 & 996 & 8 & 615 \\
5. & UmaChock CF Jamune-5 & 94.50 & 15.0 & 1,223 & 856 & 9 & 460 \\
6 & Siddha Batasan CF Jamune-6 & 115.70 & 23.0 & 1,738 & 1217 & 11 & 850 \\
\hline & Total & $\mathbf{6 4 7 . 8 5}$ & $\mathbf{1 1 7 . 0}$ & $\mathbf{7 , 8 3 2}$ & $\mathbf{5 , 4 8 3}$ & $\mathbf{8}$ & 3,965 \\
\hline
\end{tabular}


Table 3: Total and harvestable amount of A. marmelos fruits and pulp

\begin{tabular}{|c|c|c|c|c|c|c|c|}
\hline \multirow{2}{*}{ S.N. } & \multirow{2}{*}{$\begin{array}{l}\text { Name and address } \\
\text { of CFs }\end{array}$} & \multicolumn{3}{|c|}{ Total amount of $A$. marmelos fruits } & \multicolumn{3}{|c|}{$\begin{array}{c}\text { Harvestable amount of } A . \text { marmelos } \\
\text { fruits }\end{array}$} \\
\hline & & $\begin{array}{l}\text { Total no. } \\
\text { of fruits }\end{array}$ & $\begin{array}{l}\text { Weight of } \\
\text { fruits (kg) }\end{array}$ & $\begin{array}{l}\text { Production } \\
\text { (Kg/ha) }\end{array}$ & $\begin{array}{l}\text { No. available } \\
\text { for harvesting }\end{array}$ & $\begin{array}{l}\text { Weight of } \\
\text { fruits (kg) }\end{array}$ & $\begin{array}{l}\text { Pulp content } \\
\text { (kg) }\end{array}$ \\
\hline 1. & $\begin{array}{l}\text { Poseli CF, } \\
\text { Jamune-1 }\end{array}$ & 81,750 & 13,625 & 279 & 32,700 & 5,450 & $1,907.5$ \\
\hline 2. & $\begin{array}{l}\text { Barchyang CF } \\
\text { Jamune-2 }\end{array}$ & 140,700 & 23,450 & 147 & 56,280 & 9,380 & 3283 \\
\hline 3. & $\begin{array}{l}\text { Jyantang Pandhera } \\
\text { CF Jamune-3 }\end{array}$ & 139,650 & 23,275 & 222 & 55,860 & 9,310 & $3,258.5$ \\
\hline 4. & $\begin{array}{l}\text { Bhirpani CF } \\
\text { Jamune-4 }\end{array}$ & 149,400 & 24,900 & 201 & 59,760 & 9,960 & 3486 \\
\hline 5. & $\begin{array}{l}\text { Uma Chock CF } \\
\text { Jamune-5 }\end{array}$ & 128,400 & 21,400 & 226 & 51,360 & 8,560 & 2996 \\
\hline \multirow[t]{2}{*}{6.} & $\begin{array}{l}\text { Siddha Batasan CF } \\
\text { Jamune- } 6\end{array}$ & 182,550 & 30,425 & 263 & 73,020 & 12,170 & $4,259.5$ \\
\hline & Total & 822,450 & 137,075 & 212 & 328,980 & 54,830 & $19,190.5$ \\
\hline
\end{tabular}

\section{Information deficiency in the CFOPs}

The OPs of the studied CFs were found to have resource assessment summary of different tree species. However, most of the OPs were found to have information gap on A. marmelos and other NTFPs although the CFs were reported to possess a plenty of these resources. The reason behind was that $A$. marmelos and other NTFPs were ignored and higher priorities were given to Acacia catechu, Shorea robusta, Terminalia tomentosa and other timber-yielding species during field inventories.

\section{Conservation threats}

Poor regeneration due to the higher incidences of forest fire and grazing were observed in the $\mathrm{CFs}$, which were found to be serious threats for the conservation of this species. Besides, the thorny nature of this species creates difficulty in carrying out its tending and harvesting operations; so, some CFUGs were found to have even tendency to remove $A$. marmelos trees from their CFs.

\section{Availability of A. marmelos trees in the adjoining CFs and VDCs}

The study was concentrated in the CFs of Jamune VDC. However from the discussion with the CFUGs, field staffs of DFO and field observation, we came to know that plenty of A. marmelos trees were also found in the CFs of the adjoining VDCs such as Kotdarbar, Manpang, Ghansikuwa etc. of the district. According to the CFUG members, every alternate year is a good seed-year for $A$. marmelos; some literatures (Baral and Khadka, 2007; Poudel, 2005) also support this fact.

\section{Perception of different stakeholders}

The perception of the major stakeholders was found to be extremely positive towards the conservation and sustainable use of A. marmelos resource to support the livelihood of the CFUGs. In this regard, the Tanahun DFO together with the FECOFUN/CFUGs and all the other local organizations were found to be very much committed to playing active role in conservation and sustainable use of $A$. marmelos resource in the district.

\section{Conclusion}

The CFs of the Jamune VDC were found to be rich in the A. marmelos resource; however, there was no proper utilization of the resource. The six studied CFs were found to have possessed 54,830 $\mathrm{kg}$ annual harvestable amount of $A$. marmelos fruits with the potential of $19,190.5 \mathrm{~kg}$ of pulp production per year. With this annual production amount, the CFUGs can establish a small-scale A. marmelos processing enterprise in the locality. Moreover, other CFs in the adjoining VDCs were also reported to have possessed massive numbers of A. marmelos trees. Thus, a higher potentiality was observed for the development A. marmelos processing enterprise in the locality so as to support the livelihood of the CFUG members in the Jamune VDC of Tanahun district. However, further resource assessment of the 
adjoining CFs is necessary to find out the actual pulp production potential so as to sustain the proposed A. marmelos processing enterprise. On the other hand, higher threat to conservation of this species has been noticed due to the poor regeneration status of this species caused by forest fire and open grazing in the studied six CFs. Therefore, awareness generating activities among the concerned CFUGs should be carried out as soon as possible. Besides, preparation and implementation of regeneration protection plan with forest fire and grazing control activities are extremely necessary for management and sustainable use of $A$. marmelos resource in the Jamune VDC of Tanahun district.

\section{Acknowledgments}

We are grateful to Mr. D. R. Gautam together with the CARE Nepal, Hariyo Ban Program for their financial support to conduct this study. Similarly, we are thankful to Mr. R. B. Poudyal (District Forest Officer of Tanahun, DFO), Mr. G. Pandey, Assistant Forest Officer of Tanahun DFO, B. K. Shreshta, Chairman of the Siddha Batasan CF and the members of the CFUGs for their kind support during the study period.

\section{References}

Baral, K. and Khadka, D. 2007. Resource Inventory of Bel (Aegle marmelos) in Bardiya District. Council for Commerce and Industry (CCI), Bardiya, Nepal.

Bhattrai, D. R. 2001. Jadibuti Manjari. (Text in Nepali). Shubhash Printing Press, Kathmandu, Nepal.

CFOP. 2008a. Community Forestry Operational Plan (CFOP), Poseli Community Forest, Jamune VDC-1, Tanahun, Nepal.

CFOP.2008b. Community Forestry Operational Plan (CFOP), Barchyang Community

Forest, Jamune VDC-2, Tanahun, Nepal.

CFOP. 2008c. Community Forestry Operational Plan (CFOP), Jantang Pandhera Community Forest, Jamune VDC-3, Tanahun, Nepal.

$\begin{array}{llr}\text { CFOP. 2008d. Community } & \begin{array}{c}\text { Forestry } \\ \text { Operational Plan (CFOP), }\end{array} & \text { Bhirpani } \\ \text { Community Forest, Jamune } & \text { VDC-4, } \\ \text { Tanahun, Nepal. } & & \end{array}$

CFOP. 2008e. Community Forestry Operational Plan (CFOP), Uma Chowk Community Forest, Jamune VDC-5, Tanahun, Nepal.

CFOP. 2008f. Community Forestry Operational Plan (CFOP), Siddha Batashan Community Forest, Jamune VDC-6, Tanahun, Nepal.

DFO. 2014. Annual Report (2014). District Forest Office (DFO), Tanahun, Nepal.

DoF. 2013. Non-Timber Forest Products Inventory Guidelines (2013). Department of Forest (DoF), Kathmandu, Nepal.

Kunwar, R. M. 2006. Non-Timber Forest Products of Nepal: A Sustainable Management Approach. Centre for Biological Conservation Nepal and International Tropical Timber Organization, Japan.

Parajuli, D., Gyanwali, A. R. and Shrestha, B. M. 1998. Manual of Important Non-Timber Forest Products of Nepal. International Tropial Timber Organization/Institute of Forestry, Pokhara, Nepal, 6.

Pathak, L. N., K. C., R. and Chaudhary, C. L. 2015. Cultivation Practice of Major Tropical Non-Timber Forest Products of Nepal. Food and Agriculture Organization of the United Nations, Kathmandu, Nepal, 121-127.

Poudel, D. 2005. Including the Excluded: A ProPoor Bel Fruit Juice Making Enterprise in Nepal. International Tropical Timber Organization (ITTO), Community Forestry Training Center for Asia and the Pacific (RECOFTC), Forest Trends, RRI, Thailand, $10-19$.

Shrestha, R. 2003. Importance of Aegle marmelos in Nepal. Nepal Foresters' Association, Kathmandu. The Nepal Journal of Forestry XII (2): 68-69.

Shrestha, U. B. and Shrestha, S. 2005. Major Non-Timber Forest Products of Nepal. (Text in Nepali). Bhundi Puran Publication, Kathmandu, Nepal. 